\title{
Association Between Ambient Air Pollution And Daily Hospital Visits For Cardiovascular Diseases In Wuhan, China: A Time-Series Analysis Based On Medical Insurance Data.
}

\author{
Yongna Meng \\ Wuhan University \\ Zhihui Liu \\ Wuhan University \\ Jiayuan Hao \\ Harvard University \\ Fengxi Tao \\ Wuhan University \\ Huihui Zhang \\ Wuhan University
}

Yuehua Liu

China National Health Development Research Center

Suyang Liu ( $\sim$ dayangwater@hotmail.com )

Wuhan University

\section{Research Article}

Keywords: Air pollution, Cardiovascular diseases, CVD, Generalized additive model, GAM, Time-series

Posted Date: July 26th, 2021

DOI: https://doi.org/10.21203/rs.3.rs-685384/v1

License: (c) (i) This work is licensed under a Creative Commons Attribution 4.0 International License. Read Full License

Version of Record: A version of this preprint was published at International Journal of Environmental Health Research on March 25th, 2022. See the published version at https://doi.org/10.1080/09603123.2022.2035323. 


\section{Abstract}

Although a large number of studies have proved the adverse effects of exposure to air pollution on cardiovascular disease, few studies have done such research focusing on the medically insured population, a group of relatively healthier people representing the working population. We used generalized additive model (GAM) to estimate the short-term effects of ambient air pollution on CVDs in Wuhan, China. We extracted daily air pollution data, meteorological data, and daily hospital visits for CVDs (including hypertension, coronary heart disease [CHD], and heart disease [HD]) from November $1^{\text {st, }}$ 2013 to October $31^{\text {st }}, 2018$. For each increase of $10 \mu \mathrm{g} / \mathrm{m}^{3}$ in $\mathrm{SO}_{2}, \mathrm{NO}_{2}, \mathrm{PM}_{10}$, and $\mathrm{PM}_{2.5}$, the relative risks (RRs) of daily hospital visits for hypertension increased by 3.8\% (95\% confidence interval [Cl]: 1.8\%, 5.9\%), $2.5 \%$ (95\% Cl: $1.9 \%, 3.2 \%), 0.5 \%$ (95\% Cl: $0.2 \%, 0.7 \%)$, and $0.7 \%$ (95\% $\mathrm{Cl}: 0.3 \%, 1.1 \%)$ at lag 0, respectively; For CHD, the RRs increased by $3.6 \%$ (95\% Cl: 1.8\%, 5.5\%), 2.6\% (95\% Cl: $1.9 \%, 3.4 \%), 0.4 \%$ (95\% Cl: $0.1 \%$, $0.7 \%)$, and $0.5 \%(95 \% \mathrm{Cl}: 0.1 \%, 0.9 \%)$ at lag 0 , respectively; For HD, the RRs increased by $3.6 \%(95 \% \mathrm{Cl}$ : $1.4 \%, 5.8 \%), 2.1 \%(95 \% \mathrm{Cl}: 1.4 \%, 2.7 \%), 0.3 \%$ (95\% Cl: $0.1 \%, 0.6 \%)$, and $0.4 \%(95 \% \mathrm{Cl}: 0,0.8 \%)$ at lag 0 , respectively. We found that the influence of air pollution on daily hospital visits for CVDs is greater in the cold season than in the warm season. The results indicate that $\mathrm{NO}_{2}$ and $\mathrm{SO}_{2}$ may be potential confounders for co-pollutants in the multi-pollutant model. In conclusion, air pollutants including $\mathrm{SO}_{2}$, $\mathrm{NO}_{2}, \mathrm{PM}_{10}$, and $\mathrm{PM}_{2.5}$ may be associated with the risk of hypertension, $\mathrm{CHD}$, and $\mathrm{HD}$. Our findings not only can be used as reference for studying the financing and the allocation of medical resources in the future, but also served as a piece of evidence that supports the policymaking on air pollution and CVDs.

\section{Introduction}

Cardiovascular diseases (CVDs) are a group of disorders of the heart and blood vessels, such as coronary heart disease (heart attack) and hypertension (increased blood pressure). According to a report from the World Health Organization (WHO, 2017), CVDs are major non-communicable diseases and the number one cause of death in the world. CVDs were estimated to cause 17.9 million deaths each year and are also responsible for the disability-adjusted life years at the national level. (Dimmeler 2011; Kayikcioğlu and Oto 2020; WHO 2017; Zhou et al. 2019). The incidence of CVDs has doubled since 1990, reaching nearly 94 million in 2016, and it will continue to increase in the next ten years in China (Liu et al. 2019; Weiwei et al. 2016). The increase in the incidence of CVDs has had a serious adverse effect on economy, posing a challenge to the healthcare system and the society as a whole (Wu et al. 2016). In low- and middle-income countries, given that $80 \%$ of cardiovascular deaths occur in low- and middle-income countries, a 10\% reduction in CVD mortality from 2011 to 2025 is expected to reduce economic losses by $\$ 377$ billion US dollars (Laslett et al. 2012). According to a report of the National Center for CVDs of China, the prevalence of CVDs in China is on a continuous rise. The report estimated that 290 million people are suffering from CVDs, of which 245 million are hypertension, 11 million are coronary heart disease, and 14 million are other types of heart disease such as congenital heart disease and rheumatic heart disease (Li et al. 2017; Ma et al. 2020; Zhu et al. 2016). The risk factors for CVDs include, but are 
not limited to, unhealthy lifestyle, elevated blood pressure, hyperlipidemia, hyperglycemia, and air pollution (Lavie 2011; Shen and Ge 2018; Zhao et al. 2019).

Air pollution is a major environmental health problem worldwide. In 2016, $91 \%$ of the world's population lived in places that did not meet the WHO air quality guidelines (WHO 2018). Ambient air pollution causes more than seven million premature deaths globally each year, most of which occur in low- and middleincome countries (Landrigan et al. 2018; Orru et al. 2017; Yusuf et al. 2020). As one of the most polluted cities in China, Wuhan has experienced serious air pollution in the past decade (Mbululo et al. 2019). Evidence suggests that air pollution is a major risk factor for CVDs (Bai et al. 2019; Brook et al. 2010; Hadley et al. 2018; Nieuwenhuijsen 2018). In China, exposure to air pollution has been associated with an increase in the number of hospitalizations and deaths for CVDs (such as coronary heart disease [CHD] and hypertension) (Chen and Yang 2018; Dai et al. 2015; Phosri et al. 2019).

At present, China's epidemiological studies on air pollution and CVDs generally use disease data collected directly from hospitals, rather than medical insurance databases. As a result, the study focusing on the insured population is still a research gap. Since the population covered by basic medical insurance system mostly represents the working population that is considered healthier than the general population, research on this population has special public health significance. The basic medical insurance database that we extracted the data from is an important part of China's social insurance system. The outpatient, emergency, and hospitalization data contained in the database provide us with an opportunity to examine the relationship between air pollution exposure and CVDs.

Relying on data from the basic medical insurance database, this study used a generalized additive model (GAM) to explore the impact of short-term exposure to air pollution on hospital visits for hypertension, CHD and heart disease (HD) in Wuhan, China during 2013-2018.

\section{Methods}

\section{Data collection}

China's basic medical insurance system consists of three parts, namely basic medical insurance system for urban employees, basic medical insurance system for urban residents, and new rural cooperative medical care system. This study contains data collected at Wuhan city from the first two parts. We first randomly selected $1 \%$ of the total sample based on the ID number. Then, we selected the groups of diseases coded as CVDs. CVDs are a group of heart and blood vessel diseases, such as CHD, cerebrovascular disease, peripheral arterial vascular disease, and so on. We selected hypertension, CHD, and HD that belong to the category of CVDs as subgroups to analyze the relationship between CVD and air pollution. The data also includes the age, gender, and socioeconomic status (such as occupation) of patients with sensitive personal information removed.

Data on air pollution was collected from ten National Ambient Air Quality Monitoring Stations in Wuhan

(Fig. 1). The daily concentration of each pollutant represents 24 -h averages from all air quality monitoring 
sites in this study. Five air pollutants were included in our research, namely, nitrogen dioxide $\left(\mathrm{NO}_{2}\right)$, sulfur dioxide $\left(\mathrm{SO}_{2}\right)$, ground-level ozone $\left(\mathrm{O}_{3}\right)$, particulate matter $(\mathrm{PM})$ with aerodynamic diameter $\leq 2.5 \mu \mathrm{m}$ $\left(\mathrm{PM}_{2.5}\right)$, and $\mathrm{PM}$ with aerodynamic diameter $\leq 10 \mu \mathrm{m}\left(\mathrm{PM}_{10}\right)$. Data on meteorological factors including ambient temperature and relative humidity were obtained from the Hubei Meteorological Service Center.

\section{Statistical analysis}

We built a time-series database based on the date, air pollutant concentrations, meteorological factors, day of the week, and hospital visits for CVDs. We used descriptive analysis to show the characteristics of hospital visits for CVDs, air pollutants, and meteorological factors. The Spearman correlation was used to estimate the relationship between daily data of air pollutants and meteorological factors. A generalized additive Poisson regression model was established to explore the short-term impact of daily air pollutant levels on hospital visits for CVDs (Ravindra et al. 2019). In the GAM model, a smoothing spline function was selected to control the confounding effects of the long-term trend and meteorological factors. The Akaike Information Criterion for quasi-Poisson (Q-AIC) was conducted to determine the degrees of freedom (df) for time trend, relative humidity, and temperature. The model is as below:

$\log \left[E\left(y_{t}\right)\right]=\beta X_{t}+D O W+n s($ time, 8$)+n s($ temperature, 5) $+\mathrm{ns}($ humidity, 3$)+$ intercept

Where $y_{t}$ is the number of hospital visits at day t; $E(y t)$ indicates the expected number of hospital visits for CVDs on day $t ; X t$ represents the concentrations of air pollutants on day $t ; \beta$ indicates the regression coefficient, $n s$ means a natural smoothing spline function, and $D O W$ is an indicator variable meaning "day of the week". According to the minimum value of Q-AIC, we selected a smooth function of $8 \mathrm{df}$ to control for long-term effects, $5 \mathrm{df}$ to control temperature, and $3 \mathrm{df}$ to control relative humidity.

We conducted single-pollutant models to explore the short-term effects of each air pollutant on hospital visits for hypertension, CHD, and HD. We explored the effect by using different lag structures, including a single-day lag from the current day up to the previous 7 days (lag 0-lag 7) and moving averages of the current and previous days (lag 0-1 - lag0-7). Also, we performed the seasonal analysis by dividing the annual data into warm season (April-September) and cold season (October-March). If the correlation coefficient of two pollutants is less than 0.7 , we put them in the two-pollutant model to explore the effect of each pollutant on hospital visits for hypertension, CHD, and HD.

We conducted four sensitivity analyses to verify the robustness of the results. Firstly, we modified the df values between 7 and 9 for calendar time to achieve the best model fit. Secondly, we conducted stratified analyses by gender (male and female), age ( $<65$ and $\geq 65$ years old), and socioeconomic status (bluecollar worker and white-collar worker) to further test the reliability of the results.

All statistical analyses were conducted by R-software (version 4.0.0) using "mgcv" and "nlme" packages. The results we obtained were reported as the relative risk (RR) and $95 \%$ confidence intervals (Cls) of hospital visits for CVDs associated with a $10 \mu \mathrm{g} / \mathrm{m}^{3}$ increase in air pollutant concentrations. Effects with a $p$ value $<0.05$ were considered statistically significant. 


\section{Results}

The descriptive statistics of air pollutants, meteorological factors, hypertension, CHD, HD from November 2013 to October 2018 were shown in Table 1. During the five-year study period, 1,153,045 patients with hypertension, 180,777 patients with CHD, and 202,683 patients with HD were included in our analysis. The average daily hospital visits for hypertension, CHD, HD were 631,98 , and 110 , respectively. There were more hospital visits for patients with hypertension in men than women, but the opposite is true for CHD. Hospital visits for hypertension, CHD, HD were higher in the elderly ( $\geq 65$ years old) and blue-collar workers. The daily mean concentrations of $\mathrm{SO}_{2}, \mathrm{NO}_{2}, \mathrm{O}_{3}, \mathrm{PM}_{10}$, and $\mathrm{PM}_{2.5}$ were $17.50 \mu \mathrm{g} / \mathrm{m}^{3}, 47.60$ $\mu \mathrm{g} / \mathrm{m}^{3}, 55.47 \mu \mathrm{g} / \mathrm{m}^{3}, 96.32 \mu \mathrm{g} / \mathrm{m}^{3}$, and $63.31 \mu \mathrm{g} / \mathrm{m}^{3}$, respectively. The average ambient temperature and relative humidity were $17.28^{\circ} \mathrm{C}$ and $78.25 \%$ in the 1,827 days of observation during $2013-2018$. The distribution of air pollutant concentrations, meteorological factors, and hospital visits for hypertension, $\mathrm{CHD}$, and $\mathrm{HD}$ is presented in Fig. S1. 
Table 1

The summary statistics of air pollutants, meteorological factors, and hospital visits for hypertension, coronary heart disease (CHD), and heart disease (HD) in Wuhan, China from November 1st, 2013 to October 31 st, 2018.

\begin{tabular}{|c|c|c|c|c|c|c|c|c|}
\hline Daily data & $\mathbf{N}$ & Mean & SD & Min & P25 & Median & P75 & Max \\
\hline $\mathrm{SO}_{2}\left(\mu \mathrm{g} / \mathrm{m}^{3}\right)$ & 1817 & 17.50 & 16.23 & 2 & 7 & 13 & 22 & 112 \\
\hline $\mathrm{NO}_{2}\left(\mu \mathrm{g} / \mathrm{m}^{3}\right)$ & 1817 & 47.60 & 20.98 & 11 & 31 & 43 & 60 & 132 \\
\hline $\mathrm{O}_{3}\left(\mu \mathrm{g} / \mathrm{m}^{3}\right)$ & 1817 & 55.47 & 28.51 & 3 & 32 & 53 & 76 & 190 \\
\hline $\mathrm{PM}_{10}\left(\mu \mathrm{g} / \mathrm{m}^{3}\right)$ & 1817 & 96.32 & 56.35 & 0 & 55 & 86 & 123 & 406 \\
\hline $\mathrm{PM}_{2.5}\left(\mu \mathrm{g} / \mathrm{m}^{3}\right)$ & 1817 & 63.31 & 45.13 & 5 & 32 & 51 & 80 & 298 \\
\hline Ambient temperature $\left({ }^{\circ} \mathrm{C}\right)$ & 1827 & 17.28 & 8.98 & -3 & 9.5 & 18.4 & 24.9 & 34 \\
\hline Relative humidity (\%) & 1827 & 78.25 & 9.81 & 46 & 71.2 & 78.8 & 85.9 & 99 \\
\hline \multicolumn{9}{|l|}{ Hypertension (counts/day) } \\
\hline \multicolumn{9}{|l|}{ Gender } \\
\hline Female & 560,919 & 307.02 & 309.52 & 18 & 129 & 200 & 313 & 1624 \\
\hline Male & 592,119 & 324.09 & 380.99 & 13 & 115 & 176 & 299 & 2004 \\
\hline \multicolumn{9}{|l|}{ Age } \\
\hline$<65$ & 509,960 & 279.12 & 271.84 & 20 & 118 & 181 & 291 & 1429 \\
\hline$\geq 65$ & 643,081 & 351.99 & 419.56 & 13 & 124 & 199 & 325 & 2215 \\
\hline \multicolumn{9}{|l|}{ Socioeconomic factors } \\
\hline Blue-collar worker & 592,771 & 324.45 & 325.45 & 24 & 138 & 214 & 335 & 1756 \\
\hline White-collar worker & 206,644 & 113.11 & 115.43 & 6 & 44 & 76 & 124 & 574 \\
\hline Total & 1153,045 & 631.11 & 689.42 & 37 & 245 & 377 & 613 & 3628 \\
\hline \multicolumn{9}{|l|}{ CHD (counts/day) } \\
\hline \multicolumn{9}{|l|}{ Gender } \\
\hline Female & 91,622 & 50.15 & 30.88 & 6 & 29 & 44 & 59 & 199 \\
\hline Male & 89,154 & 48.80 & 34.80 & 2 & 26 & 422 & 55 & 226 \\
\hline
\end{tabular}

CHD: Coronary heart disease; HD: Heart disease; SD: Standard deviation; Min: Minimum; 


\begin{tabular}{|lllllllll|}
\hline Daily data & N & Mean & SD & Min & P25 & Median & P75 & Max \\
\hline$<65$ & 59,955 & 32.82 & 21.82 & 2 & 18 & 28 & 39 & 134 \\
$\geq 65$ & 120,821 & 66.13 & 43.91 & 3 & 38 & 57 & 75 & 291 \\
\hline Socioeconomic factors & & & & & & & & \\
\hline Blue-collar worker & 99,918 & 54.69 & 33.62 & 5 & 31 & 48 & 65 & 231 \\
\hline White-collar worker & 31,050 & 17 & 10.88 & 0 & 9 & 15 & 22 & 69 \\
\hline Total & 180,777 & 98.95 & 64.74 & 8 & 56 & 86 & 111 & 425 \\
\hline HD (counts/day) & & & & & & & & \\
\hline Gender & & & & & & & & \\
\hline Female & 89,883 & 49.20 & 47.47 & 1 & 18 & 33 & 58 & 280 \\
\hline Male & 112,798 & 61.74 & 72.59 & 2 & 18 & 36 & 64 & 469 \\
\hline Age & & & & & & & & \\
\hline$<65$ & 78,739 & 43.10 & 45.40 & 1 & 12 & 28 & 52 & 249 \\
\hline$\geq 65$ & 123,942 & 67.84 & 74.61 & 2 & 24 & 41 & 70 & 483 \\
\hline Socioeconomic factors & & & & & & & & \\
\hline Blue-collar worker & 106,540 & 58.31 & 61.87 & 2 & 20 & 36 & 66 & 450 \\
\hline White-collar worker & 35,673 & 19.53 & 19.86 & 0 & 6 & 13 & 24 & 118 \\
\hline Total & 202,683 & 110.94 & 119.12 & 4 & 37 & 68 & 121 & 732 \\
\hline CHD: Coronary heart disease; HD: Heart disease; SD: Standard deviation; Min: Minimum; & \\
\hline
\end{tabular}

Table S1 shows the Pearson's correlation coefficients of air pollutants, ambient temperature, and relative humidity, which range from 0.007 (ambient temperature and relative humidity) to $0.740\left(\mathrm{PM}_{2.5}\right.$ and $\mathrm{PM}_{10}$ ). $\mathrm{SO}_{2}, \mathrm{NO}_{2}, \mathrm{PM}_{10}$, and $\mathrm{PM}_{2.5}$ were all positively correlated with each other and were negatively correlated with ambient temperature and relative humidity. $\mathrm{O}_{3}$ was positively correlated with ambient temperature $(r=0.659)$, while it was negatively correlated with the remaining four air pollutants and relative humidity.

Figure 2 shows the RRs and $95 \%$ Cls of hospital visits for hypertension, CHD, and HD associated with a $10 \mu \mathrm{g} / \mathrm{m}^{3}$ increase in pollutant concentrations at lag $0,1,2,3,0-3$ in the single pollutant model. The complete results regarding the single-day lag model and the cumulative day lag model were shown in Fig. S2. The effects of exposure to air pollution on hypertension, $\mathrm{CHD}$, and $\mathrm{HD}$ have similar trends. $\mathrm{SO}_{2}, \mathrm{NO}_{2}$, $\mathrm{PM}_{10}$, and $\mathrm{PM}_{2.5}$ were significantly associated with daily hospital visits for CVDs. In the single-day lag model, the effects of the four air pollutants on daily hospital visits for CVDs is highest at lag 0 and then 
shows a downward trend. For each $10 \mu \mathrm{g} / \mathrm{m}^{3}$ increase in $\mathrm{SO}_{2}, \mathrm{NO}_{2}, \mathrm{PM}_{10}$, and $\mathrm{PM}_{2.5}$ concentrations, the RRs of daily hospital visits for hypertension increased by $3.8 \%(95 \% \mathrm{Cl}: 1.8 \%, 5.9 \%), 2.5 \%(95 \% \mathrm{Cl}: 1.9 \%$, $3.2 \%), 0.5 \%(95 \% \mathrm{Cl}: 0.2 \%, 0.7 \%)$, and $0.7 \%(95 \% \mathrm{Cl}: 0.3 \%, 1.1 \%)$ at lag 0 , respectively; the RRs of daily hospital visits for $\mathrm{CHD}$ increased by $3.6 \%$ (95\% Cl: $1.8 \%, 5.5 \%), 2.6 \%(95 \% \mathrm{Cl}: 1.9 \%, 3.4 \%), 0.4 \%(95 \% \mathrm{Cl}$ : $0.1 \%, 0.7 \%)$, and $0.5 \%(95 \% \mathrm{Cl}: 0.1 \%, 0.9 \%)$ at lag 0 , respectively; the RRs of daily hospital visits for $\mathrm{HD}$ increased by $3.6 \%$ (95\% Cl: $1.4 \%, 5.8 \%), 2.1 \%$ (95\% Cl: $1.4 \%, 2.7 \%), 0.3 \%(95 \% \mathrm{Cl}: 0.1 \%, 0.6 \%)$, and $0.4 \%$ (95\% Cl: $0,0.8 \%)$ at lag 0 , respectively. In the multi-day lag model, the effects of $\mathrm{SO}_{2}$ and $\mathrm{NO}_{2}$ on hypertension, CHD, and HD remain significantly at lag $0-3$.

The seasonal analysis shows the RRs and $95 \%$ Cls of hospital visits for hypertension, CHD, and HD associated with a $10 \mu \mathrm{g} / \mathrm{m}^{3}$ increase in pollutant concentrations at different lag days during the cold and warm seasons (Fig. 3). In both the single-day lag model and the multi-day lag model, $\mathrm{SO}_{2}, \mathrm{NO}_{2}, \mathrm{PM}_{10}$, and $\mathrm{PM}_{2.5}$ have a stronger effect on hypertension, $\mathrm{CHD}$, and $\mathrm{HD}$ in the cold season than in the hot season. On the contrary, $\mathrm{O}_{3}$ has a stronger effect in the warm season than in the cold season.

The results of RR and $95 \%$ Cls of hospital visits for hypertension, CHD, and HD based on the single- and two-pollutant models were shown in Table 2. The results of multi-pollutant models were presented at Table S2. Considering the collinearity between pollutants, the correlation coefficient between the two pollutants has to be less than 0.7 in order to include them in the two-pollutant model, otherwise would be excluded from the analysis. The effect of $\mathrm{PM}_{10}$ and $\mathrm{PM}_{2.5}$ on $\mathrm{CHD}$ and $\mathrm{HD}$ decreased after the adjustment for $\mathrm{SO}_{2}$ in the two-pollutant model. Meanwhile, after adjusting for $\mathrm{NO}_{2}$, the effects of $\mathrm{SO}_{2}$ and $\mathrm{PM}_{2.5}$ on hypertension, $\mathrm{CHD}$, and $\mathrm{HD}$ become statistically insignificant. In addition, $\mathrm{NO}_{2}$ can strengthen the effect of $\mathrm{O}_{3}$ on $\mathrm{CHD}$ and $\mathrm{HD}$. 
Table 2

Estimated relative risks (RRs) and 95\% confidence intervals (Cls) of hospital visits for a 10 $\mu \mathrm{g} / \mathrm{m}^{3}$ increase of pollutant concentrations based on the single- and two-pollutant models. Pollutant

$\operatorname{RR}(95 \% \mathrm{Cl})$

\begin{tabular}{|c|c|c|c|c|}
\hline & & Hypertension & $\mathrm{CHD}$ & $H D$ \\
\hline \multirow[t]{5}{*}{$\mathrm{SO}_{2}$} & & $1.038(1.018-1.059)$ & $1.036(1.018-1.055)$ & $1.036(1.014-1.058)$ \\
\hline & $+\mathrm{NO}_{2}$ & $0.989(0.966-1.014)$ & $1.002(0.980-1.023)$ & $0.991(0.965-1.018)$ \\
\hline & $+\mathrm{O}_{3}$ & $1.038(1.018-1.058)$ & $1.036(1.018-1.055)$ & $1.035(1.013-1.058)$ \\
\hline & $+\mathrm{PM}_{10}$ & $1.027(1.005-1.049)$ & $1.030(1.010-1.051)$ & $1.028(1.004-1.053)$ \\
\hline & $+\mathrm{PM}_{2.5}$ & $1.030(1.009-1.052)$ & $1.033(1.014-1.052)$ & $1.032(1.009-1.055)$ \\
\hline \multirow[t]{4}{*}{$\mathrm{NO}_{2}$} & & $1.025(1.019-1.032)$ & $1.026(1.019-1.034)$ & $1.021(1.014-1.027)$ \\
\hline & $+\mathrm{SO}_{2}$ & $1.027(1.019-1.036)$ & $1.026(1.017-1.035)$ & $1.023(1.014-1.031)$ \\
\hline & $+\mathrm{O}_{3}$ & $1.025(1.019-1.032)$ & $1.026(1.019-1.034)$ & $1.021(1.014-1.028)$ \\
\hline & $+\mathrm{PM}_{2.5}$ & $1.026(1.018-1.033)$ & $1.028(1.019-1.037)$ & $1.023(1.015-1.030)$ \\
\hline \multirow[t]{5}{*}{$\mathrm{O}_{3}$} & & $1.028(0.982-1.077)$ & $1.051(0.993-1.112)$ & $1.040(0.994-1.089)$ \\
\hline & $+\mathrm{SO}_{2}$ & $1.028(0.981-1.076)$ & $1.050(0.993-1.112)$ & $1.040(0.993-1.088)$ \\
\hline & $+\mathrm{NO}_{2}$ & $1.038(0.991-1.086)$ & $1.059(1.001-1.121)$ & $1.048(1.001-1.096)$ \\
\hline & $+\mathrm{PM}_{10}$ & $1.025(0.979-1.074)$ & $1.048(0.990-1.109)$ & $1.038(0.991-1.087)$ \\
\hline & $+\mathrm{PM}_{2.5}$ & $1.027(0.981-1.075)$ & $1.050(0.992-1.111)$ & $1.039(0.992-1.088)$ \\
\hline \multirow[t]{3}{*}{$\mathrm{PM}_{10}$} & & $1.005(1.002-1.007)$ & $1.004(1.001-1.007)$ & $1.003(1.001-1.006)$ \\
\hline & $+\mathrm{SO}_{2}$ & $1.003(1.000-1.006)$ & $1.002(0.999-1.005)$ & $1.002(0.999-1.005)$ \\
\hline & $+\mathrm{O}_{3}$ & $1.005(1.002-1.007)$ & $1.004(1.001-1.007)$ & $1.003(1.001-1.006)$ \\
\hline \multirow[t]{4}{*}{$\mathrm{PM}_{2.5}$} & & $1.007(1.003-1.011)$ & $1.005(1.001-1.009)$ & $1.004(1.000-1.008)$ \\
\hline & $+\mathrm{SO}_{2}$ & $1.005(1.001-1.009)$ & $1.002(0.998-1.007)$ & $1.002(0.998-1.007)$ \\
\hline & $+\mathrm{NO}_{2}$ & $1.000(0.995-1.004)$ & $0.998(0.994-1.003)$ & $0.998(0.993-1.002)$ \\
\hline & $+\mathrm{O}_{3}$ & $1.007(1.003-1.011)$ & $1.005(1.001-1.009)$ & $1.004(1.000-1.008)$ \\
\hline
\end{tabular}


Table 3 shows the results of the stratified analysis by gender (male and female), age ( $<65$ and $\geq 65$ years old), and socioeconomic status (blue-collar worker and white-collar worker) at lag 0 . We have not observed considerable differences in the effects of air pollution on CVDs in terms of age, gender, and socioeconomic status. All results regarding the stratified analysis are presented in Fig. S3 (gender), Fig. S4 (age), and Fig. S5 (socioeconomic status). Since the number of CVDs in late 2017 to the most of 2018 was significantly higher than the previous year (see Fig. S1), we compared the differences in the effects of air pollution on CVD in the months when the number of visits was high and the effects in the previous year (the months when the number of visits was low). The results show that similar trends were observed in both periods (Fig. S6).

Table 3. Estimated relative risks (RRs) and $95 \%$ confidence intervals (Cls) of hospital visits for a 10 $\mu \mathrm{g} / \mathrm{m}^{3}$ increase of pollutant concentrations by gender, age, and socioeconomic factors among patients had hypertension, coronary heart disease (CHD), and heart disease (HD). 


\begin{tabular}{|c|c|c|c|c|c|c|}
\hline \multirow[t]{2}{*}{ Variables } & \multicolumn{2}{|l|}{ Gender } & \multicolumn{2}{|l|}{ Age } & \multicolumn{2}{|c|}{ Socioeconomic factors } \\
\hline & Female & Male & $<65$ & $\geq 65$ & $\begin{array}{l}\text { Blue-collar } \\
\text { worker }\end{array}$ & $\begin{array}{l}\text { White-collar } \\
\text { worker }\end{array}$ \\
\hline \multicolumn{7}{|c|}{ Hypertension } \\
\hline $\mathrm{SO}_{2}$ & $\begin{array}{l}1.044 \\
(1.024- \\
1.064)\end{array}$ & $\begin{array}{l}1.032 \\
(1.011- \\
1.054)\end{array}$ & $\begin{array}{l}1.036 \\
(1.018- \\
1.055)\end{array}$ & $\begin{array}{l}1.040 \\
(1.017- \\
1.063)\end{array}$ & $\begin{array}{l}1.036 \\
(1.015- \\
1.057)\end{array}$ & $\begin{array}{l}1.028 \\
(1.004- \\
1.052)\end{array}$ \\
\hline $\mathrm{NO}_{2}$ & $\begin{array}{l}1.027 \\
(1.021- \\
1.034)\end{array}$ & $\begin{array}{l}1.023 \\
(1.017- \\
1.030)\end{array}$ & $\begin{array}{l}1.023 \\
(1.017- \\
1.029)\end{array}$ & $\begin{array}{l}1.027 \\
(1.020- \\
1.034)\end{array}$ & $\begin{array}{l}1.026 \\
(1.019- \\
1.033)\end{array}$ & $\begin{array}{l}1.026 \\
(1.018- \\
1.034)\end{array}$ \\
\hline $\mathrm{O}_{3}$ & $\begin{array}{l}1.025 \\
(0.977- \\
1.075)\end{array}$ & $\begin{array}{l}1.031 \\
(0.984- \\
1.081)\end{array}$ & $\begin{array}{l}1.021 \\
(0.977- \\
1.066)\end{array}$ & $\begin{array}{l}1.033 \\
(0.982- \\
1.087)\end{array}$ & $\begin{array}{l}1.048 \\
(0.996- \\
1.103)\end{array}$ & $\begin{array}{l}1.057 \\
(0.999- \\
1.119)\end{array}$ \\
\hline $\mathrm{PM}_{10}$ & $\begin{array}{l}1.005 \\
(1.003- \\
1.008)\end{array}$ & $\begin{array}{l}1.004 \\
(1.002- \\
1.007)\end{array}$ & $\begin{array}{l}1.004 \\
(1.002- \\
1.006)\end{array}$ & $\begin{array}{l}1.005 \\
(1.002- \\
1.008)\end{array}$ & $\begin{array}{l}1.005 \\
(1.002- \\
1.007)\end{array}$ & $\begin{array}{l}1.005 \\
(1.002- \\
1.008)\end{array}$ \\
\hline $\mathrm{PM}_{2.5}$ & $\begin{array}{l}1.008 \\
(1.004- \\
1.012)\end{array}$ & $\begin{array}{l}1.006 \\
(1.002- \\
1.011)\end{array}$ & $\begin{array}{l}1.006 \\
(1.003- \\
1.010)\end{array}$ & $\begin{array}{l}1.008 \\
(1.003- \\
1.012)\end{array}$ & $\begin{array}{l}1.007 \\
(1.003- \\
1.011)\end{array}$ & $\begin{array}{l}1.006 \\
(1.002- \\
1.011)\end{array}$ \\
\hline \multicolumn{7}{|l|}{$\mathrm{CHD}$} \\
\hline $\mathrm{SO}_{2}$ & $\begin{array}{l}1.043 \\
(1.024- \\
1.062)\end{array}$ & $\begin{array}{l}1.029 \\
(1.009- \\
1.049)\end{array}$ & $\begin{array}{l}1.042 \\
(1.021- \\
1.063)\end{array}$ & $\begin{array}{l}1.034 \\
(1.015- \\
1.053)\end{array}$ & $\begin{array}{l}1.036 \\
(1.017- \\
1.056)\end{array}$ & $\begin{array}{l}1.022 \\
(0.997- \\
1.048)\end{array}$ \\
\hline $\mathrm{NO}_{2}$ & $\begin{array}{l}1.027 \\
(1.018- \\
1.035)\end{array}$ & $\begin{array}{l}1.026 \\
(1.018- \\
1.035)\end{array}$ & $\begin{array}{l}1.023 \\
(1.014- \\
1.032)\end{array}$ & $\begin{array}{l}1.028 \\
(1.020- \\
1.036)\end{array}$ & $\begin{array}{l}1.026 \\
(1.018- \\
1.035)\end{array}$ & $\begin{array}{l}1.022 \\
(1.011- \\
1.033)\end{array}$ \\
\hline $\mathrm{O}_{3}$ & $\begin{array}{l}1.046 \\
(0.985- \\
1.111)\end{array}$ & $\begin{array}{l}1.056 \\
(0.992- \\
1.124)\end{array}$ & $\begin{array}{l}1.077 \\
(1.009- \\
1.149)\end{array}$ & $\begin{array}{l}1.038 \\
(0.978- \\
1.103)\end{array}$ & $\begin{array}{l}1.051 \\
(0.985- \\
1.121)\end{array}$ & $\begin{array}{l}1.059 \\
(0.975- \\
1.149)\end{array}$ \\
\hline $\mathrm{PM}_{10}$ & $\begin{array}{l}1.004 \\
(1.001- \\
1.007)\end{array}$ & $\begin{array}{l}1.004 \\
(1.001- \\
1.007)\end{array}$ & $\begin{array}{l}1.003 \\
(0.999- \\
1.006)\end{array}$ & $\begin{array}{l}1.005 \\
(1.002- \\
1.008)\end{array}$ & $\begin{array}{l}1.004 \\
(1.001- \\
1.008)\end{array}$ & $\begin{array}{l}1.003 \\
(0.999- \\
1.008)\end{array}$ \\
\hline $\mathrm{PM}_{2.5}$ & $\begin{array}{l}1.005 \\
(1.000- \\
1.009)\end{array}$ & $\begin{array}{l}1.005 \\
(1.000- \\
1.009)\end{array}$ & $\begin{array}{l}1.003 \\
(0.998- \\
1.008)\end{array}$ & $\begin{array}{l}1.006 \\
(1.001- \\
1.010)\end{array}$ & $\begin{array}{l}1.005 \\
(1.000- \\
1.009)\end{array}$ & $\begin{array}{l}1.005 \\
(0.999- \\
1.010)\end{array}$ \\
\hline \multicolumn{7}{|l|}{ HD } \\
\hline $\mathrm{SO}_{2}$ & $\begin{array}{l}1.049 \\
(1.025- \\
1.074)\end{array}$ & $\begin{array}{l}1.024 \\
(0.999- \\
1.049)\end{array}$ & $\begin{array}{l}1.013 \\
(0.998- \\
1.040)\end{array}$ & $\begin{array}{l}1.048 \\
(1.025- \\
1.072)\end{array}$ & $\begin{array}{l}1.039 \\
(1.015- \\
1.065)\end{array}$ & $\begin{array}{l}1.042 \\
(1.010- \\
1.074)\end{array}$ \\
\hline $\mathrm{NO}_{2}$ & $\begin{array}{l}1.023 \\
(1.016- \\
1.031)\end{array}$ & $\begin{array}{l}1.019 \\
(1.012- \\
1.026)\end{array}$ & $\begin{array}{l}1.016 \\
(1.008- \\
1.023)\end{array}$ & $\begin{array}{l}1.024 \\
(1.017- \\
1.031)\end{array}$ & $\begin{array}{l}1.024 \\
(1.016- \\
1.031)\end{array}$ & $\begin{array}{l}1.021 \\
(1.011- \\
1.030)\end{array}$ \\
\hline
\end{tabular}




\begin{tabular}{|lllllll|}
$\mathrm{O}_{3}$ & $\begin{array}{l}1.034 \\
(0.982-\end{array}$ & $\begin{array}{l}1.046 \\
(0.994-\end{array}$ & $\begin{array}{l}1.047 \\
(0.992-\end{array}$ & $\begin{array}{l}1.036 \\
(0.986-\end{array}$ & $\begin{array}{l}1.051 \\
(0.997-\end{array}$ & $\begin{array}{l}1.078 \\
(1.008-\end{array}$ \\
& $1.089)$ & $1.101)$ & $1.104)$ & $1.090)$ & $1.108)$ & $1.153)$ \\
\hline & & & & & & \\
$\mathrm{PM}_{10}$ & $(1.005$ & 1.002 & 1.002 & 1.004 & 1.004 & 1.003 \\
& $(1.002-$ & $(1.000-$ & $(0.999-$ & $(1.002-$ & $(1.002-$ & $(0.999-$ \\
& $1.007)$ & $1.005)$ & $1.005)$ & $1.007)$ & $1.007)$ & $1.007)$ \\
\hline & & & & & & \\
$\mathrm{PM}_{2.5}$ & 1.005 & 1.004 & 1.003 & 1.005 & 1.006 & 1.007 \\
& $(1.000-$ & $(0.999-$ & $(0.998-$ & $(1.000-$ & $(1.001-$ & $(1.001-$ \\
& $1.009)$ & $1.009)$ & $1.008)$ & $1.009)$ & $1.010)$ & $1.013)$ \\
\hline
\end{tabular}

\section{Discussion}

We conducted a time-series analysis to explore the association between air pollution and hospital visits for CVDs from 2013 to 2018 in Wuhan, China. We found that the short-term exposures to $\mathrm{SO}_{2}, \mathrm{NO}_{2}, \mathrm{PM}_{10}$, and $\mathrm{PM}_{2.5}$ were significantly associated with the risk of hypertension, $\mathrm{CHD}$, and $\mathrm{HD}$. Our results show that the largest effect of air pollution on CVDs occurred at lag 0 (single-day lag) and lag 0-3 (multi-day lag). We also found that the association is stronger in the cold season than in the warm season. As far as we know, this is the first study to explore the association between daily hospital visits for CVDs and air pollution in Wuhan based on medical insurance data.

In the past few decades, the environment in China has faced great challenges due to rapid industrial development and urbanization. The increase in the number of vehicles and energy consumption and the decrease in green coverage has affected air quality to varying degrees. Continuous haze weather is commonly seen in China, causing serious environmental hazards, especially in cities with large populations (Maji et al. 2018; Xu et al. 2019). Wuhan, the largest city in central China, has a population of 12 million and is one of the most polluted cities in China. Our study suggested that the 24-hour average concentrations of $\mathrm{PM}_{10}\left(96.09 \mu \mathrm{g} / \mathrm{m}^{3}\right)$ and $\mathrm{PM}_{2.5}\left(63.03 \mu \mathrm{g} / \mathrm{m}^{3}\right)$ far exceeded the air quality standards set by the WHO ( $50 \mu \mathrm{g} / \mathrm{m}^{3}$ and $25 \mu \mathrm{g} / \mathrm{m}^{3}$, respectively). The impact of air pollution on the cardiovascular system is frequently reported worldwide. A study conducted in Ahvaz, Iran indicated that the risk of hospital admission for CVDs increased by $0.6 \%$ (95\% Cl: 0.1 to $1 \%)$ for every increase of $10 \mu \mathrm{g} / \mathrm{m}^{3}$ of $\mathrm{NO}_{2}$ at lag 0 (Dastoorpoor et al. 2019). Dai et al. (2015) reported that for every $10 \mu \mathrm{g} / \mathrm{m}^{3}$ increase in the concentrations of $\mathrm{PM}_{10}$ and $\mathrm{SO}_{2}$, the risk of out-of-hospital coronary deaths increased by $0.49 \%(95 \% \mathrm{Cl}$ : 0.11 to $0.88 \%$ ) and $0.88 \%$ (95\% Cl: 0.14 to $1.62 \%$ ) at lag 0 , respectively. A time-series study by Zhang et al. (2017) found that exposures to $\mathrm{SO}_{2}, \mathrm{NO}_{2}$, and $\mathrm{PM}_{10}$ were associated with a $5.26 \%(95 \% \mathrm{Cl}$ : $3.31-$ $7.23 \%), 2.71 \%(95 \% \mathrm{Cl}: 1.23-4.22 \%)$, and $0.68 \%(95 \% \mathrm{Cl}: 0.33-1.04 \%)$ increase in cardiovascular mortality at lag $0-3$. Another study conducted by systematic review and meta-Analysis reported that short-term exposure to $\mathrm{SO}_{2}, \mathrm{PM}_{2.5}$, and $\mathrm{PM}_{10}$ is significantly associated with a $4.6 \%(1.2-8.1 \%), 6.9 \%(0.3-14.1 \%)$, and $2.4 \%(1.6-3.2 \%)$ increase in the risk of hypertension (Cai et al. 2016). Our findings are generally consistent with the results of past studies in two dimensions. One is the effects of air pollution on cardiovascular disease and the second is the time or moment when the strongest effects occur. However, some studies have also reported different findings. A time-series study conducted in Guangzhou, China 
found that PM has no significant effect on CVDs (Ge et al. 2018). In addition, we did not observe a significant association between the short-term exposure to $\mathrm{O}_{3}$ and the increased mortality of CVDs that many studies have already reported (Bero Bedada et al. 2016; Mazidi and Speakman 2018; Sicard et al. 2019; Zhang et al. 2019). This inconsistency may be due to the following reasons: 1 ) the statistical methods used in these studies are different from ours; 2 ) the different geographical location of the study may cause differences in results; 3 ) the demographic characteristics of the exposed population are different.

The latest scientific statement from the American Heart Association believes that there is a causal relationship between exposure to $\mathrm{PM}_{2.5}$ and cardiovascular morbidity and mortality (Brook et al. 2010). The possible physiological and molecular mechanisms involved are still in the process of exploration. One of the possible mechanisms is that inhalation of particulate matter in the environment can cause the body to produce pro-oxidant substances (reactive oxygen species, etc.), pro-inflammatory biological mediators (interleukin 6, etc.), the acute phase reactants (C-reactive protein, etc.), and vasoactive hormones (endothelin, etc.), resulting in systemic inflammation and oxidative stress. These reactions in the lung will eventually affect the cardiovascular system through blood circulation (Gurgueira et al. 2002; Q Liu et al. 2019; Mannucci et al. 2019; Pope et al. 2016). Meanwhile, evidence suggests that particulate matter can pass through the lung epithelium into the circulatory system or interact with lung receptors (direct action) to induce an acute cardiovascular response (Fiordelisi et al. 2017; Nemmar et al. 2001; Nemmar et al. 2002). In addition, air pollutants can cause the body's autonomic nervous system to malfunction and activate pathways of the central nervous system, leading to increased blood pressure and heart rate variability. Due to inhalation of air pollutants, the nose, bronchus, and lung $\mathrm{C}$ nerve fiber subtypes will activate many receptors that can affect sensory nerves. (Franklin et al. 2015; Rajagopalan et al. 2018).

The seasonal analysis shows that the effect of most air pollutants on hospital visits for CVDs is stronger in the cold season than in the warm season except for $\mathrm{O}_{3}$. The results are consistent with previous studies (Song et al. 2019; Tong et al. 2014; Ye et al. 2016). Like our study, a previous study (Brook and Kousha 2015) also found that the effect of $\mathrm{O}_{3}$ on CVDs is also more pronounced in the warm season rather than in the cold season. One possible explanation for the different $\mathrm{O}_{3}$ results between studies is that the chemical composition and source of air pollutants may vary by region and season (Krall et al. 2013).

We found that all pollutants except $\mathrm{O}_{3}$ are statistically significant for cardiovascular disease in the singlepollutant model. However, in the two-pollutant model, after adjusting for $\mathrm{SO}_{2}$ or $\mathrm{NO}_{2}$, the effects of other pollutants on hypertension, CHD, and HD have been changed (intensified or weakened). This may suggest that they are confounding factors for other pollutants and cardiovascular disease. It may be due to the collinearity between air pollutants, given that the difference in correlation coefficients between pollutants is not obvious (VanderWeele 2009). Therefore, to avoid collinearity, we include two pollutants with a correlation coefficient of less than 0.7 into the two-pollutant model. 
In addition to the single-pollutant models, we also constructed two-pollutant models to assess the effect of air pollution on CVDs. To avoid collinearity, two pollutants included in the model have to meet the criteria that their correlation coefficients must be less than 0.7. After including the second pollutant in the model, the results are not much different from those produced by the single-pollutant model. However, it should be noticed that after adjusting for $\mathrm{SO}_{2}$ or $\mathrm{NO}_{2}$, the effects of co-pollutants on CVDs are universally changed (intensified or weakened). This may indicate that these two pollutants are the major confounders between air pollutants and cardiovascular diseases.

This study has several limitations. First, we obtained the data on pollutants from air quality monitoring stations rather than personal exposure samplers. Also, we assume that everyone is exposed to the same level of air pollution each day. This may lead to exposure misclassification, an inevitable flaw in such type of ecological studies. Second, the findings of this study are based on data collected in a single city, so generalizing the conclusions to other cities or regions will produce bias. Third, our data comes from basic medical insurance data, so the conclusion does not apply to the general public. However, this is also an advantage of our study. People who are covered by medical insurance are generally healthier than the general public, so investigating the impact of air pollution on such a population has special public health significance.

\section{Declarations}

Acknowledgements Thanks for the tutor's careful guidance and the help of the research team.

Author's contributions YNM and ZHL made formal analysis, software analysis, data curation, conceptualization, and original draft. JYH made software analysis and validation. FXT and HHZ made validation and search resources. YHL made supervision. SYL made data curation, conceptualization, and reviewed the manuscript.

Funding Not applicable.

Ethics approval and consent to participate Not applicable.

Consent for publication Not applicable.

Availability of data and materials The datasets generated and/or analysed during the current study are not publicly available but are available from the corresponding author on reasonable request.

Competing interests The authors declare no competing interests.

\section{References}

1. Bai L, Weichenthal S, Kwong JC, Burnett RT, Hatzopoulou M, Jerrett M, et al. 2019. Associations of long-term exposure to ultrafine particles and nitrogen dioxide with increased incidence of congestive 
heart failure and acute myocardial infarction. Am J Epidemiol 188:151-159. http://dx.doi.org/10.1093/aje/kwy194.

2. Bero Bedada G, Raza A, Forsberg B, Lind T, Ljungman P, Pershagen G, et al. 2016. Short-term exposure to ozone and mortality in subjects with and without previous cardiovascular disease. Epidemiology 27:663-669. http://dx.doi.org/10.1097/EDE.0000000000000520.

3. Brook RD, Rajagopalan S, Pope CA, Brook JR, Bhatnagar A, Diez-Roux AV, et al. 2010. Particulate matter air pollution and cardiovascular disease: An update to the scientific statement from the american heart association. Circulation 121:2331-2378. https://doi.org/10.1161/cir.0b013e3181dbece1.

4. Brook RD, Kousha T. 2015. Air pollution and emergency department visits for hypertension in edmonton and calgary, canada: A case-crossover study. Am J Hypertens 28:11211126. https://doi.org/10.1093/ajh/hpu302.

5. Cai Y, Zhang B, Ke W, Feng B, Lin H, Xiao J, et al. 2016. Associations of short-term and long-term exposure to ambient air pollutants with hypertension: A systematic review and meta-analysis. Hypertension 68:62-70. https://doi.org/10.1161/hypertensionaha.116.07218.

6. Chen C-C, Yang C-Y. 2018. Association between gaseous air pollution and hospital admissions for hypertension in taipei, taiwan. J Toxicol Environ Health A 81:53-59. https://doi.org/10.1080/15287394.2017.1395573.

7. Dai J, Chen R, Meng X, Yang C, Zhao Z, Kan H. 2015. Ambient air pollution, temperature and out-ofhospital coronary deaths in shanghai, china. Environ Pollut 203:116121. https://doi.org/10.1016/j.envpol.2015.03.050.

8. Dastoorpoor M, Sekhavatpour Z, Masoumi K, Mohammadi MJ, Aghababaeian H, Khanjani N, et al. 2019. Air pollution and hospital admissions for cardiovascular diseases in ahvaz, iran. Sci Total Environ 652:1318-1330. https://doi.org/10.1016/j.scitotenv.2018.10.285.

9. Dimmeler S. 2011. Cardiovascular disease review series. EMBO molecular medicine 3:697. https://doi.org/10.1002/emmm.201100182.

10. Fiordelisi A, Piscitelli P, Trimarco B, Coscioni E, laccarino G, Sorriento D. 2017. The mechanisms of air pollution and particulate matter in cardiovascular diseases. Heart Fail Rev 22:337347. https://doi.org/10.1007/s10741-017-9606-7.

11. Franklin BA, Brook R, Arden Pope C. 2015. Air pollution and cardiovascular disease. Curr Probl Cardiol 40:207-238. https://doi.org/10.1016/j.cpcardiol.2015.01.003.

12. Ge E, Lai K, Xiao X, Luo M, Fang Z, Zeng Y, Ju H, Zhong N. 2018. Differential effects of size-specific particulate matter on emergency department visits for respiratory and cardiovascular diseases in Guangzhou, China. Environ Pollut 243:336-345. https://doi.org/10.1016/j.envpol.2018.08.068.

13. Gurgueira SA, Lawrence J, Coull B, Murthy GGK, González-Flecha B. 2002. Rapid increases in the steady-state concentration of reactive oxygen species in the lungs and heart after particulate air pollution inhalation. Environmental health perspectives 110:749-

755. https://doi.org/10.1289/ehp.02110749.

Page 15/21 
14. Hadley MB, Baumgartner J, Vedanthan R. 2018. Developing a clinical approach to air pollution and cardiovascular health. Circulation 137:725-742. https://doi.org/10.1161/circulationaha.117.030377.

15. Kayikcioğlu M, Oto A. 2020. Control and management of cardiovascular disease in turkey. Circulation 141:7-9. https://doi.org/10.1161/circulationaha.119.037606.

16. Krall JR, Anderson GB, Dominici F, Bell ML, Peng RD. 2013. Short-term exposure to particulate matter constituents and mortality in a national study of u.S. Urban communities. Environmental health perspectives 121:1148-1153. https://doi.org/10.1289/ehp.1206185.

17. Landrigan PJ, Fuller R, Acosta NJR, Adeyi O, Arnold R, Basu NN, et al. 2018. The lancet commission on pollution and health. Lancet 391:462-512. https://doi.org/10.1016/s0140-6736(17)32345-0.

18. Laslett LJ, Alagona P, Clark BA, Drozda JP, Saldivar F, Wilson SR, et al. 2012. The worldwide environment of cardiovascular disease: Prevalence, diagnosis, therapy, and policy issues: A report from the american college of cardiology. J Am Coll Cardiol 60:S1-

49. https://doi.org/10.1016/j.jacc.2012.11.002.

19. Lavie CJ. 2011. Exercise and cardiovascular diseases--a matter of life or death. Progress in cardiovascular diseases 53:385-386. https://doi.org/10.1016/j.pcad.2011.03.001.

20. Li Y, Yang L, Wang L, Zhang M, Huang Z, Deng Q, et al. 2017. Burden of hypertension in china: A nationally representative survey of 174,621 adults. Int J Cardiol 227:516523. https://doi.org/10.1016/j.ijcard.2016.10.110.

21. Liu Q, Gu X, Deng F, Mu L, Baccarelli AA, Guo X, et al. 2019. Ambient particulate air pollution and circulating c-reactive protein level: A systematic review and meta-analysis. Int J Hyg Environ Health 222:756-764. https://doi.org/10.1016/j.ijheh.2019.05.005.

22. Liu S, Li Y, Zeng X, Wang H, Yin P, Wang L, et al. 2019. Burden of cardiovascular diseases in china, 1990-2016: Findings from the 2016 global burden of disease study. JAMA Cardiol 4:342352. https://doi.org/10.1001/jamacardio.2019.0295.

23. Maji KJ, Dikshit AK, Arora M, Deshpande A. 2018. Estimating premature mortality attributable to pm exposure and benefit of air pollution control policies in china for 2020. Sci Total Environ 612:683693. https://doi.org/10.1016/j.scitotenv.2017.08.254.

24. Ma L-Y, Chen W-W, Gao R-L, Liu L-S, Zhu M-L, Wang Y-J, et al. 2020. China cardiovascular diseases report 2018: An updated summary. J Geriatr Cardiol 17:1-8. https://doi.org/10.11909/j.issn.16715411.2020.01.001.

25. Mannucci PM, Harari S, Franchini M. 2019. Novel evidence for a greater burden of ambient air pollution on cardiovascular disease. Haematologica 104:2349-2357. https://doi.org/10.3324/haematol.2019.225086.

26. Mazidi M, Speakman JR. 2018. Impact of obesity and ozone on the association between particulate air pollution and cardiovascular disease and stroke mortality among us adults. J Am Heart Assoc 7. https://doi.org/10.1161/jaha.117.008006.

27. Mbululo Y, Qin J, Yuan Z, Nyihirani F, Zheng X. 2019. Boundary layer perspective assessment of air pollution status in wuhan city from 2013 to 2017. Environmental monitoring and assessment 
191:69. https://doi.org/10.1007/s10661-019-7206-9.

28. Nemmar A, Vanbilloen H, Hoylaerts MF, Hoet PH, Verbruggen A, Nemery B. 2001. Passage of intratracheally instilled ultrafine particles from the lung into the systemic circulation in hamster. Am J Respir Crit Care Med 164:1665-1668. https://doi.org/10.1164/ajrccm.164.9.2101036.

29. Nemmar A, Hoet PHM, Vanquickenborne B, Dinsdale D, Thomeer M, Hoylaerts MF, et al. 2002. Passage of inhaled particles into the blood circulation in humans. Circulation 105:411414. https://doi.org/10.1161/hc0402.104118.

30. Nieuwenhuijsen MJ. 2018. Influence of urban and transport planning and the city environment on cardiovascular disease. Nat Rev Cardiol 15:432-438. https://doi.org/10.1038/s41569-018-0003-2.

31. Orru H, Ebi KL, Forsberg B. 2017. The interplay of climate change and air pollution on health. Curr Environ Health Rep 4:504-513. https://doi.org/10.1007/s40572-017-0168-6.

32. Phosri A, Ueda K, Phung VLH, Tawatsupa B, Honda A, Takano H. 2019. Effects of ambient air pollution on daily hospital admissions for respiratory and cardiovascular diseases in bangkok, thailand. Sci Total Environ 651:1144-1153. https://doi.org/10.1016/j.scitotenv.2018.09.183.

33. Pope CA, Bhatnagar A, McCracken JP, Abplanalp W, Conklin DJ, O'Toole T. 2016. Exposure to fine particulate air pollution is associated with endothelial injury and systemic inflammation. Circ Res 119:1204-1214. https://doi.org/10.1161/circresaha.116.309279.

34. Rajagopalan S, Al-Kindi SG, Brook RD. 2018. Air pollution and cardiovascular disease: Jacc state-ofthe-art review. J Am Coll Cardiol 72:2054-2070. https://doi.org/10.1016/j.jacc.2018.07.099.

35. Ravindra K, Rattan P, Mor S, Aggarwal AN. 2019. Generalized additive models: Building evidence of air pollution, climate change and human health. Environ Int 132:104987. https://doi.org/10.1016/j.envint.2019.104987.

36. Shen C, Ge J. 2018. Epidemic of cardiovascular disease in china: Current perspective and prospects for the future. Circulation 138:342-344. https://doi.org/10.1161/circulationaha.118.033484.

37. Sicard P, Khaniabadi YO, Perez S, Gualtieri M, De Marco A. 2019. Effect of o, pm and pm on cardiovascular and respiratory diseases in cities of france, iran and italy. Environ Sci Pollut Res Int 26:32645-32665. https://doi.org/10.1007/s11356-019-06445-8.

38. Song J, Lu M, Lu J, Chao L, An Z, Liu Y, et al. 2019. Acute effect of ambient air pollution on hospitalization in patients with hypertension: A time-series study in shijiazhuang, china. Ecotoxicol Environ Saf 170:286-292. https://doi.org/10.1016/j.ecoenv.2018.11.125.

39. Tong L, Li K, Zhou Q. 2014. Promoted relationship of cardiovascular morbidity with air pollutants in a typical chinese urban area. PLoS One 9:e108076. https://doi.org/10.1371/journal.pone.0108076.

40. VanderWeele TJ. 2009. On the relative nature of overadjustment and unnecessary adjustment. Epidemiology 20:496-499. https://doi.org/10.1097/ede.0b013e3181a82f12.

41. Weiwei C, Runlin G, Lisheng L, Manlu Z, Wen W, Yongjun W, et al. 2016. Outline of the report on cardiovascular diseases in china, 2014. Eur Heart J Suppl

18. https://doi.org/10.1093/eurheartj/suw030.

Page $17 / 21$ 
42. WHO. 2017. Cardiovascular diseases (CVDs). https://www.who.int/en/news-room/factsheets/detail/cardiovascular-diseases-(cvds).

43. WHO. 2018. Ambient (outdoor) air pollution. https://www.who.int/news-room/factsheets/detail/ambient-(outdoor)-air-quality-and-health.

44. Wu Y, Benjamin EJ, MacMahon S. 2016. Prevention and control of cardiovascular disease in the rapidly changing economy of china. Circulation 133:25452560. https://doi.org/10.1161/circulationaha.115.008728.

45. Xu W, Sun J, Liu Y, Xiao Y, Tian Y, Zhao B, et al. 2019. Spatiotemporal variation and socioeconomic drivers of air pollution in china during 2005-2016. J Environ Manage 245:6675. https://doi.org/10.1016/j.jenvman.2019.05.041.

46. Ye X, Peng L, Kan H, Wang W, Geng F, Mu Z, et al. 2016. Acute effects of particulate air pollution on the incidence of coronary heart disease in shanghai, china. PLoS One 11:e0151119. https://doi.org/10.1371/journal.pone.0151119.

47. Yusuf S, Joseph P, Rangarajan S, Islam S, Mente A, Hystad P, et al. 2020. Modifiable risk factors, cardiovascular disease, and mortality in 155722 individuals from 21 high-income, middle-income, and low-income countries (pure): A prospective cohort study. Lancet 395:795808. https://doi.org/10.1016/s0140-6736(19)32008-2.

48. Zhang C, Ding R, Xiao C, Xu Y, Cheng H, Zhu F, et al. 2017. Association between air pollution and cardiovascular mortality in hefei, china: A time-series analysis. Environ Pollut 229:790797. https://doi.org/10.1016/j.envpol.2017.06.022.

49. Zhang J, Chen Q, Wang Q, Ding Z, Sun H, Xu Y. 2019. The acute health effects of ozone and pm on daily cardiovascular disease mortality: A multi-center time series study in china. Ecotoxicol Environ Saf 174:218-223. https://doi.org/10.1016/j.ecoenv.2019.02.085.

50. Zhao D, Liu J, Wang M, Zhang X, Zhou M. 2019. Epidemiology of cardiovascular disease in china: Current features and implications. Nat Rev Cardiol 16:203-212. https://doi.org/10.1038/s41569-0180119-4.

51. Zhou M, Wang H, Zeng X, Yin P, Zhu J, Chen W, et al. 2019. Mortality, morbidity, and risk factors in china and its provinces, 1990-2017: A systematic analysis for the global burden of disease study 2017. Lancet 394:1145-1158. https://doi.org/10.1016/s0140-6736(19)30427-1.

52. Zhu K-F, Wang Y-M, Zhu J-Z, Zhou Q-Y, Wang N-F. 2016. National prevalence of coronary heart disease and its relationship with human development index: A systematic review. Eur J Prev Cardiol 23:530-543. https://doi.org/10.1177/2047487315587402.

\section{Figures}




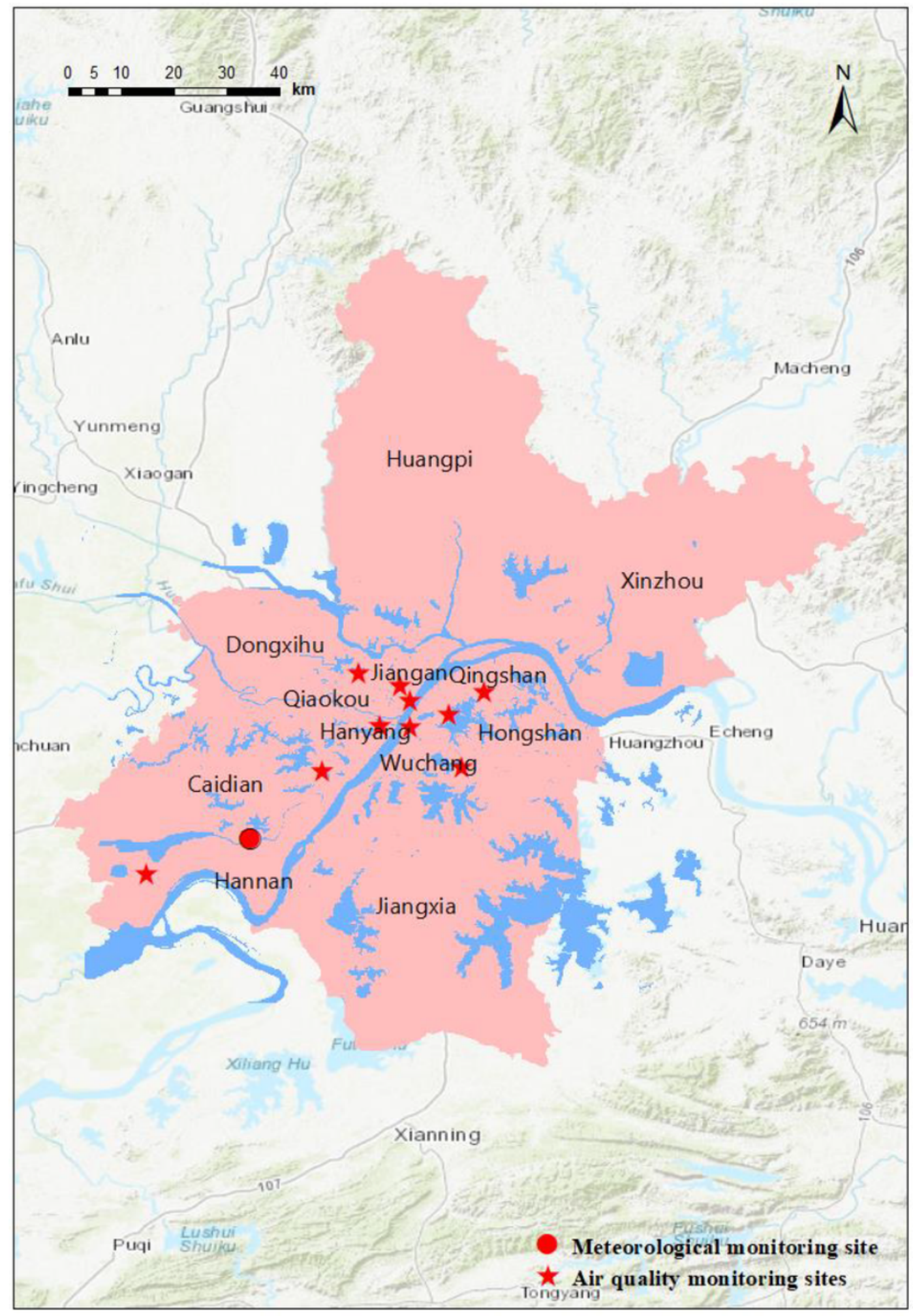

Figure 1

Map of Wuhan showing the location of weather and air quality monitoring sites. 

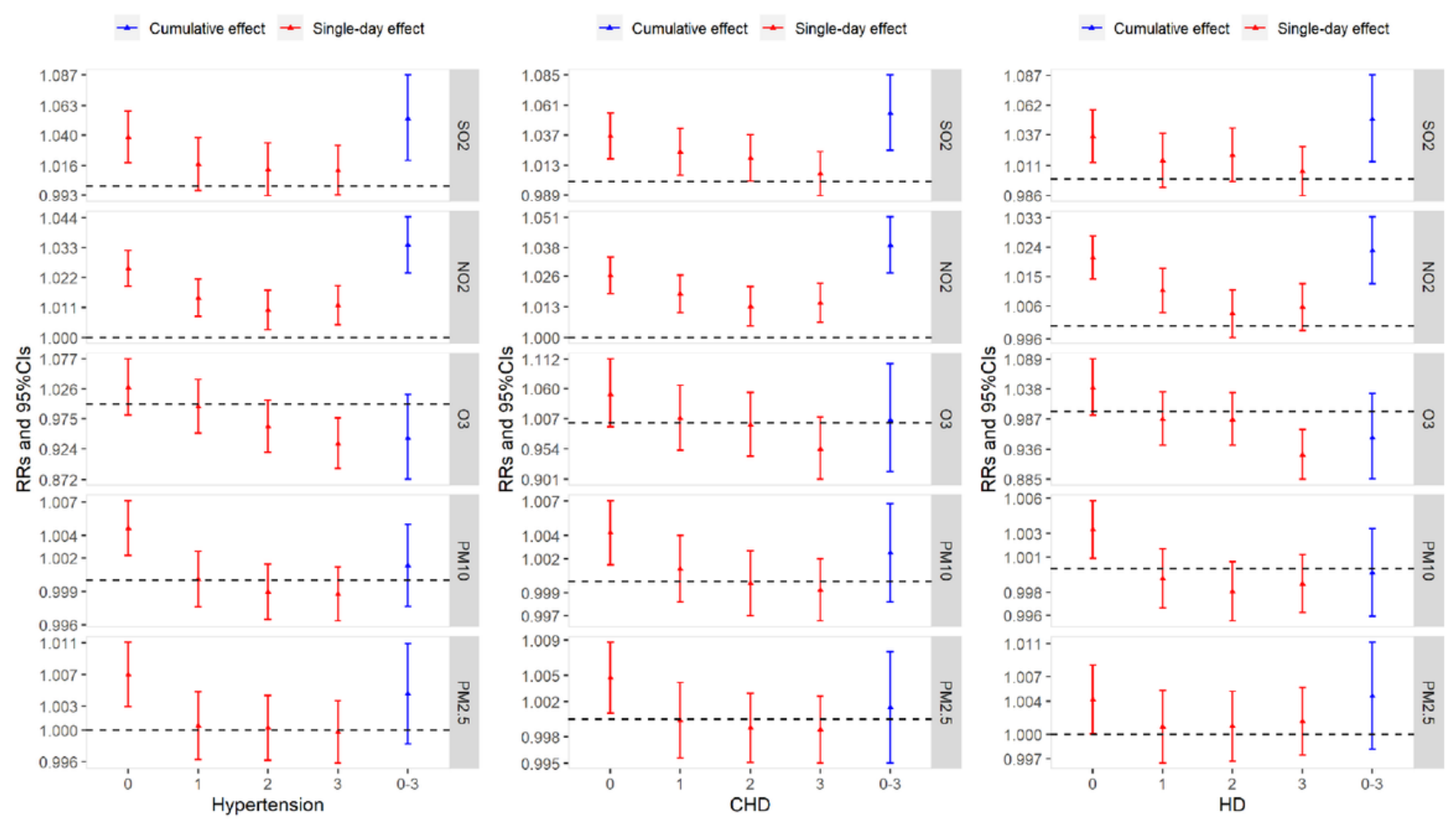

\section{Figure 2}

Estimated relative risks (RRs) and 95\% confidence intervals (Cls) of hospital visits for selected Cardiovascular diseases (CVDs) associated with a $10 \mu \mathrm{g} / \mathrm{m} 3$ increase of pollutant concentrations on different lag days.
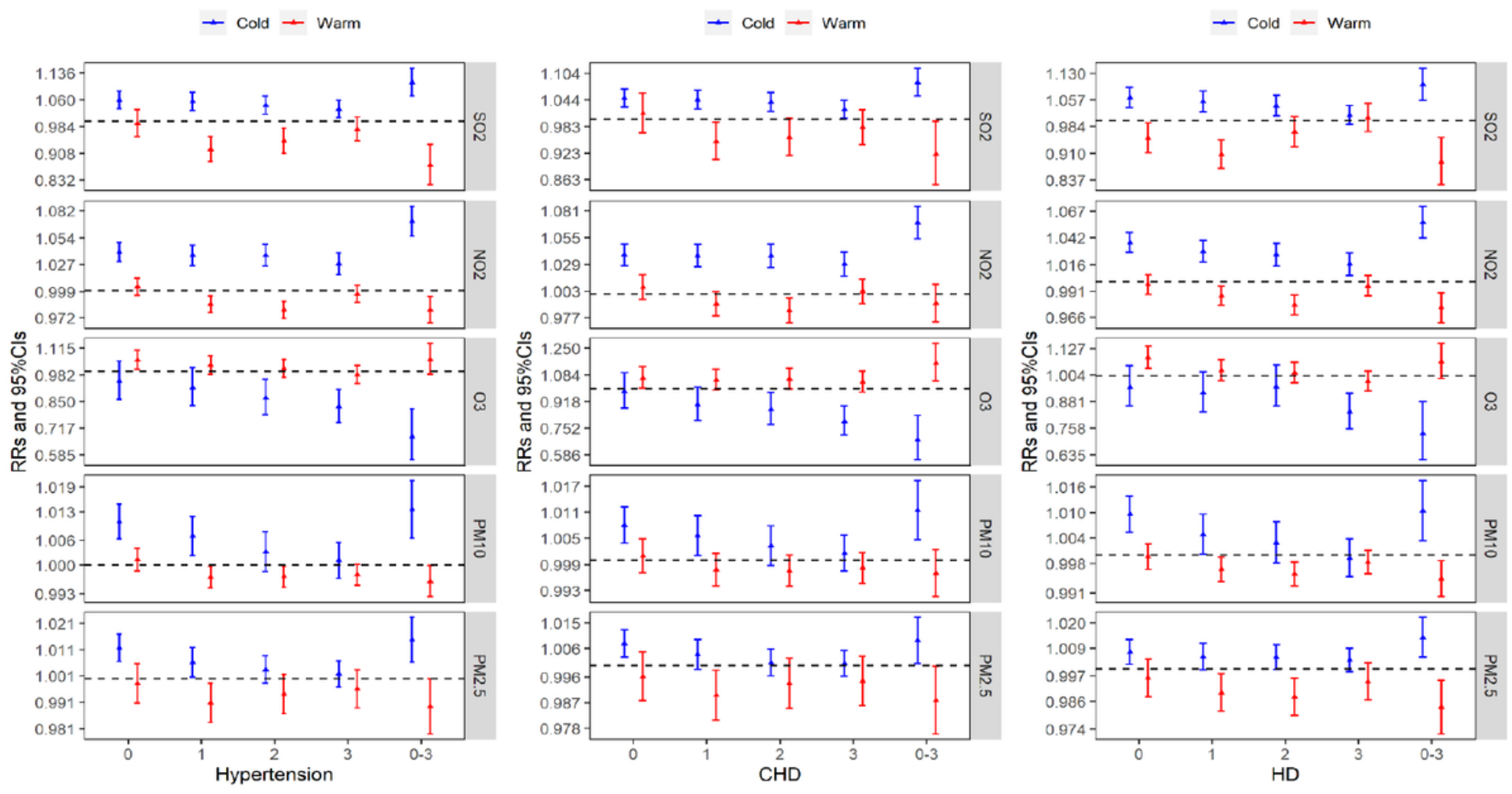


\section{Figure 3}

Estimated relative risks (RRs) and 95\% confidence intervals (Cls) of hospital visits for selected Cardiovascular diseases (CVDs) associated with a $10 \mu \mathrm{g} / \mathrm{m} 3$ increase of pollutant concentrations on different lag days in the cold (October to March) and warm (April to September) seasons.

\section{Supplementary Files}

This is a list of supplementary files associated with this preprint. Click to download.

- SupplementaryMaterial.docx 